\title{
ANALISIS MITIGASI POTENSI LIKUIFAKSI (STUDI KASUS : PROYEK PEMBANGKIT LISTRIK TENAGA GAS DAN UAP LOMBOK, NUSA TENGGARA BARAT)
}

\author{
Daniel Yudha Prayoga ${ }^{1}$, I Wayan Redana ${ }^{2}$ dan Annisa Maria Hidayati ${ }^{3}$ \\ 1,2,3 Program Studi Magister Teknik Sipil Universitas \\ UdayanaEmail: yudha.daniel1501@gmail.com
}

doi: https://doi.org/10.24843/SPEKTRAN.2021.v09.i01.p06

\begin{abstract}
ABSTRAK
Likuifaksi memiliki dampak terhadap pondasi karena dapat mereduksi nilai daya dukung aksial dan lateral yang akibatnya akan menyebabkan kegagalan infrastruktur. Proyek PLTGU Lombok dipilih menjadi daerah studi karena daerah tersebut diprediksi memiliki potensi likuifaksi. Pada area building, sistem pondasi yang direncanakan adalah tiang pancang. Area tersebut memiliki potensi likuifaksi di lapisan tanah kedalaman berkisar antara 2 sampai 30 meter. Penelitian ini membahas juga perubahan konfigurasi pondasi tiang yang digunakan sebelum dan sesudah likuifaksi. Untuk alternatif mitigasi likuifaksi, dianalisis perbaikan tanah dengan menggunakan stone column yang dapat meningkatkan kuat geser tanah. Analisis potensi likuifaksi dilakukan dengan metode tsuchida chart dan NCEER, sedangkan metode analisis daya dukung tiang tunggal menggunakan Software LPILE v5.0 dan analisis untuk menentukan konfigurasi tiang kelompok menggunakan Software GROUP v8.0. Saat kondisi likuifaksi, hasil penelitian menunjukan daya dukung aksial tekan tidak mengalami reduksi dikarenakan ujung tiang tertanam pada lapisan tanah keras sehingga daya dukung aksial tekan telah mencapai kapasitas maksimumnya. Daya dukung aksial tarik mengalami reduksi berkisar 1 hingga 47\%. Daya dukung lateral mengalami reduksi berkisar 0 hingga 48\%. Pada analisis daya dukung tiang grup, perbedaan jumlah pile yang diperlukan dengan kondisi sebelum dan setelah likuifaksi cukup signifikan. Jumlah tiang yang diperlukan ketika kondisi sebelum likuifaksi adalah 121 tiang dengan panjang tiang $30 \mathrm{~m}$ sedangkan jumlah tiang yang diperlukan untuk kondisi setelah terjadi likuifaksi adalah 169 tiang dengan panjang tiang $30 \mathrm{~m}$. Untuk area non building, perbaikan tanah yang cocok pada lokasi studi adalah stone column dengan diameter 0.6 $\mathrm{m}$, spasi $0.7 \mathrm{~m}$, dan pola segitiga.
\end{abstract}

Kata kunci: likuifaksi, pondasi, daya dukung aksial, daya dukung lateral, stone column

\section{LIQUIFACTION POTENTIAL MITIGATION ANALYSIS}

\begin{abstract}
Liquefaction has an impact on the foundation because it can reduce the value of axial and lateral bearing capacity which as a result will cause infrastructure failure. PLTGU Lombok project was selected as the study area because the area is predicted to have the liquefaction potential. In the building area, the planned foundation system by piles. The area has the liquefaction potential in the subsoil with a depth of between 2 and 30 meters. This study also discusses changes configuration of piles used before and after liquefaction. For liquefaction mitigation alternatives, analysis of soil improvement using stone columns can increase soil shear strength. The analysis of liquefaction potential was calculated using the Tsuchida and NCEER graph method, while the single pile bearing capacity analysis method used the LPILE v5.0 software and the analysis to determine the group layout was using the GROUP v8.0 software. During liquefaction conditions, the results showed that the compressive axial bearing capacity did not occur a reduction because the pile tip was embedded in a hard soil layer so that the compressive axial bearing capacity had reached its maximum capacity. The axial bearing capacity is reduced in the range of 1 to $47 \%$. The lateral bearing capacity is reduced in the range of 0 to $48 \%$. In the group pile bearing capacity analysis, the difference in the number of piles required with the conditions before and after liquefaction is quite significant. The number of piles required during the pre-liquefaction condition is 121 piles with $30 \mathrm{~m}$ long piles, while the number of piles required for post-liquefaction conditions is 169 piles with $30 \mathrm{~m}$ long piles. For non-building areas, suitable soil improvements in the study location are stone columns with a diameter of $0.6 \mathrm{~m}$, a spacing of $0.7 \mathrm{~m}$, and a triangular pattern.
\end{abstract}

Keywords: Liquefaction, Foundation, Stone Column, Axial Bearing Capacity, Lateral Bearing Capacity 


\section{PENDAHULUAN}

Pada pembangunan konstruksi seringkali ditemukan kondisi yang tidak ideal dalam perencanaan dan pelaksanaan pekerjaan konstruksi. Ada kalanya pekerjaan konstruksi dilaksanakan di atas lapisan tanah granular yang memiliki relative density yang rendah dengan muka air yang tinggi. Salah satu permasalahan di bidang geoteknik yang kerap terjadi akibat tingginya frekuensi gempa, terutama yang terjadi pada lapisan tanah granular di Indonesia adalah likuifaksi. Pada saat likuifaksi terjadi kekuatan geser tanah tereduksi akibat beban seismic yang dihasilkan gempa bumi. Pada saat gempa, terjadi guncangan pada tanah yang menyebabkan lapisan tanah pasir dengan kepadatan yang rendah mengalami kontraksi sehingga terjadi peningkatan tegangan air pori. Seiring dengan naiknya tegangan air pori yang diakibatkan guncangan gempa, tegangan efektif menjadi berkurang bahkan bisa menjadi tidak mempunyai tegangan efektif sama sekali sehingga mengubah tanah berpasir menjadi cair. Peristiwa likuifaksi juga dapat memberikan dampak terhadap pondasi, karena berpotensi menurunkan daya dukung aksial dan lateral pada pondasi yang dapat menyebabkan kegagalan pada infrastruktur. Mengetahui nilai penurunan daya dukung aksial dan lateral pada pondasi akibat peristiwa likuifaksi menjadi penting.

Proyek PLTGU di Mataram, Lombok dipilih menjadi daerah studi penelitian. Proyek ini bertujuan untuk memfasilitasi kebutuhan listrik pulau NTB dengan rencana kapasitas sebesar $150 \mathrm{Mw}$. Daerah ini diprediksi memiliki potensi likuifaksi berdasarkan data pengujian tanah sehingga diperlukan solusi untuk mengatasinya. Dalam penelitian ini analisis potensi likuifaksi dilakukan dengan metode Tsuchida Chart dan NCEER, sedangkan metode analisis daya dukung tiang tunggal menggunakan Software Lpile, lalu akan dibahas juga mengenai perubahan konfigurasi pondasi tiang yang digunakan sebelum dan sesudah peristiwa likuifaksi terjadi pada proyek ini menggunakan Software GROUP v.8.0. Selain perhitungan dampak likuifaksi terhadap pondasi, salah satu upaya untuk memitigasi potensi likuifaksi adalah dengan melakukan upaya perbaikan tanah. Salah satu metode perbaikan tanah yang sudah cukup lama dikenal untuk menangani tanah pasir lepas kondisi jenuh air yang berpotensi likuifaksi adalah stone column.

Perbaikan tanah dengan stone column dapat meningkatkan kepadatan pada tanah sehingga meningkatkan kekuatan tanah dan mengurangi penurunan tanah (settlement). Metode perbaikan tanah bekerja dengan baik dalam mereduksi potensi likuifaksi pada lapisan tanah. Harapan dari penelitian ini adalah sebagai rekomendasi dan referensi tambahan dalam mengatasi potensi likuifaksi di daerah studi

\section{LIKUIFAKSI}

Likuifaksi adalah proses perubahan kondisi tanah pasir yang jenuh air menjadi cair akibat meningkatnya tekanan air pori yang harganya menjadi sama dengan tekanan total oleh sebab terjadinya beban dinamik, sehingga tegangan efektif tanah menjadi nol.

\subsection{Analisis Potensi Likuifaksi}

2.1.1 Metode Tsuchida Chart

Menurut Tsuchida (1970), distribusi butiran tanah dapat dijadikan bahan analisis pendahuluan terhadap potensi likuifaksi tanah. Tsuchida mengemukakan sebuah chart gradasi ukuran butiran tanah untuk memperkirakan kerentanan tanah yang mengalami likuifaksi. Berdasarkan gradasi tanah, Tsuchida mengusulkan batas-batas distribusi ukuran butiran yang peka terhadap likuifaksi seperti ditunjukkan pada gambar Gambar 1.

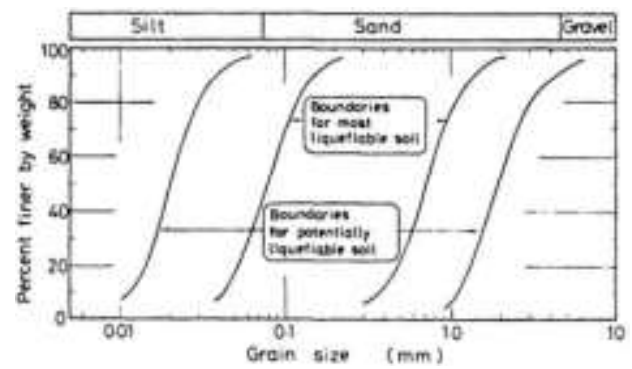

Gambar 1 Distribusi butiran terhadap potensi likuifaksi (Tsuchida, 1970)

Batas bawah dari ukuran partikel menunjukkan pengaruh adanya butiran halus yang menurunkan kencenderungan tanah memadat saat mengalami getaran. Butir halus yang plastis membuat butir pasir lebih sulit menggelincir antara partikel, tetapi butir halus yang tidak plastis tidak akan memberikan pengaruh apa-apa. Batas atas dari ukuran partikel diasosiasikan dengan sifat butir kasar yang permeable sehingga saat gempa dapat terjadi pelepasan tekanan air pori secara partial.

\subsubsection{Metode Simplifikasi (NCEER)}

Pada metode ini terdapat dua parameter yang sangat menentukan hasil analisis, yaitu pembebanan cyclic yang dialami tanah atau Cyclic Stress Ratio (CSR) dan tahanan tanah terhadap likuifaksi atau Cyclic Resistance Ratio (CRR). 
Likuifaksi tidak akan terjadi apabila tahanan tanah (CRR) lebih besar dibandingkan pembebanan cyclic yang dialami tanah (CSR).

1. Cyclic Stress Ratio (CSR)

CSR adalah nilai perbandingan antara tegangan geser rata-rata yang diakibatkan oleh gempa dengan tegangan vertikal efektif di setiap lapisan tanah. Jika kolom tanah sedalam $z$ di ibaratkan bersifat kaku maka tegangan geser maksimum pada dasar kolom dapat dihitung dengan persamaan (1) :

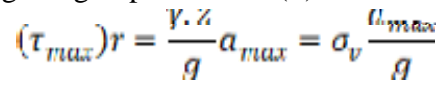

Dimana $a_{\max }$ adalah percepatan gempa maksimum di permukaan, $\gamma$ adalah berat jenis tanah pada kedalaman $z$ dan $\sigma_{v}$ adalah tegangan vertikal total. Pada kenyataannya tanah tidak berperilaku kaku namun bergerak fleksibel tergantung kedalaman tanah tersebut. Oleh karena itu, tegangan geser maksimum untuk tanah yang bergerak secara fleksibel pada kedalaman tertentu dapat dihitung dengan persamaan (2):

$$
\tau_{\max } d=\mathrm{rd}\left(\tau_{\max }\right) \bar{r}
$$

Dimana, $r d$ adalah koefisien reduksi tegangan geser. Untuk memudahkan perhitungan, T. F. Blake (1996) mengeluarkan persamaan untuk mengetahui nilai faktor reduksi $(r d)$ seperti persamaan (3):

$$
r d-\frac{\left(1,000-0,4113 z^{0,5}+0,04052 z+0,001753 z^{1,5}\right)}{\left(1,000-0,4117 z^{0,5}+0,05729 z-0,006205 z^{1,5}+0,001210 z^{2}\right)}
$$

Pada saat terjadi gempa, tiap-tiap elemen tanah mengalami tegangan geser. Seed dan Idriss (1971) telah mengasumsikan tegangan geser cyclic rata-rata yang bekerja pada tiap-tiap elemen tanah adalah 65\% dari tegangan geser maksimum gempa yang terjadi. Oleh karena ini, persamaan untuk menghitung nilai CSR adalah:

$$
C S R-0,65 \frac{l_{\max }}{\sigma^{\prime} v}-0,65 \frac{a_{v}}{\sigma_{y}^{\prime}} \frac{u_{\max }}{\theta} r d
$$

2. Cyclic Resistance Ratio (CRR)

Nilai Cyclic Resistance Ratio (CRR) merupakan nilai kapasitas tahanan suatu lapisan tanah terhadap tegangan cyclic. Dalam penelitian ini akan dibahas evaluasi nilai $C R R$ dengan menggunakan hasil dari uji SPT di lapangan. Nilai N-SPT pada dasarnya berbeda dengan efisiensi energi yang terukur (Schmertmann and Palacios, 1979). Dalam standar pengukuran Amerika umumnya menggunakan 55\% - 60\% efisiensi energi hammer (Kovacs et al., 1983). Berdasarkan hal tersebut, nilai $N_{60}$ direkomendasikan usebagai standar perhitungan untuk mengevaluasi potensi likuifaksi pada tanah (Seed et al., 1984). Persamaan untuk mencari nilai (N1) 60 menurut Robertson dan Wride (1998) adalah:

$$
(\mathrm{N} 1)_{60}=\mathrm{N} \cdot C_{N^{*}} \cdot C_{E_{v}} C_{B_{1}}^{*} C_{R} C_{\mathrm{S}}
$$

\begin{tabular}{|c|c|c|c|}
\hline $\begin{array}{l}\text { Factor } \\
\text { (1) }\end{array}$ & $\begin{array}{l}\text { Equipment variable } \\
\text { (2) }\end{array}$ & $\begin{array}{c}\text { Term } \\
\text { (3) }\end{array}$ & $\begin{array}{c}\text { Correction } \\
\text { (4) }\end{array}$ \\
\hline $\begin{array}{l}\text { Overburden pressure } \\
\text { Overburden pressure } \\
\text { Energy ratio } \\
\text { Energy ratio } \\
\text { Energy ratio }\end{array}$ & $\begin{array}{l}\text { - } \\
\text { Donut hammer } \\
\text { Safety hammer } \\
\text { Automatic-trip Donut- } \\
\text { type hammer }\end{array}$ & $\begin{array}{l}C_{N} \\
C_{N} \\
C_{E} \\
C_{K} \\
C_{E}\end{array}$ & $\begin{array}{l}\left(P_{v} / \sigma_{v}^{\prime}\right)^{2.5} \\
C_{N} \leq 1.7 \\
0.5-1.0 \\
0.7-1.2 \\
0.8-1.3\end{array}$ \\
\hline $\begin{array}{l}\text { Borehole diameter } \\
\text { Borehole diameter } \\
\text { Borehole diameter } \\
\text { Rod length } \\
\text { Rod length } \\
\text { Rod length } \\
\text { Rod length } \\
\text { Rod length } \\
\text { Sampling method } \\
\text { Sampling method }\end{array}$ & $\begin{array}{l}65-115 \mathrm{~mm} \\
150 \mathrm{~mm} \\
200 \mathrm{~mm} \\
<3 \mathrm{~m} \\
3-4 \mathrm{~m} \\
4-6 \mathrm{~m} \\
6-10 \mathrm{~m} \\
10-30 \mathrm{~m} \\
\text { Standard sampler } \\
\text { Sampler without liners }\end{array}$ & $\begin{array}{l}C_{B} \\
C_{B} \\
C_{B} \\
C_{R} \\
C_{R} \\
C_{R} \\
C_{R} \\
C_{R} \\
C_{S} \\
C_{S}\end{array}$ & $\begin{array}{l}1.0 \\
1.05 \\
1.15 \\
0.75 \\
0.8 \\
0.85 \\
0.95 \\
1.0 \\
1.0 \\
1.1-1.3\end{array}$ \\
\hline
\end{tabular}

Dengan, $N$ adalah nilai perlawanan penetrasi standar, $C_{N}$ adalah faktor normalisasi $\mathrm{Nm}, C_{E}$ adalah faktor koreksi dari energi hammer, $C_{B}$ adalah faktor koreksi diameter borehole, $C_{R}$ adalah faktor koreksi dari panjang rod, $C_{S}$ adalah faktor koreksi dari sampel. Nilai faktor koreksi dapat dilihat pada Tabel 1:

Tabel 1 Faktor koreksi SPT (dimodifikasi oleh Skempton (1986) dari Robertson and Wride (1998))

Nilai N-SPT meningkat seiring dengan meningkatnya nilai tegangan efektif overburden, oleh karena itu digunakan faktor koreksi tegangan efektif overburden (Seed and Idriss 1982). Faktor tersebut dihitung dengan menggunakan persamaan Liao and Whitman (1986b) :

$$
C_{N}-\left(\frac{l^{2} a}{\sigma_{w o}}\right)^{0.5}
$$

Dimana $C_{N}$ adalah normalisasi $\mathrm{N}$ terhadap tegangan efektif overburden dan $P a$ adalah $100 \mathrm{kPa}(1 \mathrm{~atm}) . C_{N}$ sebaiknya tidak melebihi nilai 1,7. Dalam perkembangannya, Seed et.al (1985) mencatat bahwa peningkatan nilai 
$C R R$ berbanding lurus dengan peningkatan fine content $(F C)$. Seed et al. mengembangkan kurva $C R R$ dengan menambahkan faktor fine content $(F C)$ pada kurva tersebut yaitu $5 \%, 15 \%$ dan $35 \%$. Nilai $C R R$ yang didapat merupakan nilai $C R R$ untuk magnitude gempa sebesar 7.5, hal ini dikarenakan data yang digunakan untuk membuat grafik ini adalah data gempa dengan magnitude 7,5. A.F. Raunch (1998) memperkirakan persamaan dari grafik tersebut sebagai persamaan (7):

$$
C R R_{7,5}=\frac{1}{34-(\mathrm{N} 1)_{60 c s}}+\frac{(\mathrm{N} 1)_{60 e s}}{135}+\frac{50}{\left[10 .(\mathrm{N} 1)_{60 c s}+45\right]^{2}}-\frac{1}{200}
$$

\section{Factor of safety}

Nilai factor of safety merupakan nilai faktor keamanan tanah terhadap potensi terjadi likuifaksi pada tanah. Jika nilai FS < 1 maka tanah berpotensi terjadi likuifaksi, sedangkan jika FS > 1 maka tanah tidak berpotensi terjadi likuifaksi. Karena nilai $C R R$ yang kita dapatkan sebelumnya adalah nilai $C R R$ untuk magnitude gempa 7.5, maka untuk mendapatkan nilai $C R R$ dengan magnitude gempa lebih besar atau lebih kecil dari 7.5 Seed dan Idriss (1982) memperkenalkan faktor koreksi Magnitude Scaling Factor (MSF) untuk dikalikan dengan nilai $C R R_{7,5}$. Untuk menghitung nilai factor of safety untuk magnitude gempa selain 7,5 digunakan persamaan sebagai berikut:

$$
\mathrm{PS}=\frac{\mathrm{CKH}_{7,5}}{\operatorname{CSR}} \times \mathrm{MSF} \times K_{a} \times \mathrm{K}_{m}
$$

Dimana, MSF adalah Magnitude Scaling Factor, Ko adalah faktor koreksi untuk tegangan efektif, $K \alpha$ adalah faktor koreksi untuk kemiringan lereng. Variabel $K \sigma$ dan $K \alpha$ biasanya diperhitungkan pada kasus khusus sehingga dalam penelitian ini nilai $K \sigma$ dan $K \alpha$ adalah 1. Untuk mencari nilai $M S F$ digunakan persamaan dari Seed and Idriss (1982) untuk magnitude < 7,5 yag ditampilkan pada persamaan (9):

$$
\text { MST }-\frac{10^{2,24}}{\mathrm{M}_{\text {MTr }}{ }^{2, F F}}
$$

Menurut Andrus and Stokoe (1997), persamaan untuk menghitung MSF dengan magnitude > 7,5 adalah:

$$
M S P=-\left(\frac{M}{7,5}\right)-2 S E
$$

\section{METODE}

Secara umum penelitian dimulai dengan melakukan studi literatur. Studi literatur yang dilakukan adalah dengan mempelajari teori dan literatur yang relevan dengan penelitian ini, yaitu tentang likuifaksi, pondasi, dan metode perbaikan tanah. Sumber literatur diperoleh dari beberapa jurnal, diktat, pedoman peraturan-peraturan, maupun bacaan lain yang merupakan sumber referensi untuk memperoleh dasar-dasar teori dan parameter parameter yang diperlukan penelitian ini. Langkah berikutnya yang dilakukan adalah pengumpulan data berupa data penyelidikan tanah, baik data penyelidikan lapangan (N-SPT) dan laboratorium proyek PLTGU di Lombok, serta data parameter gempa yang didapatkan dari buku pusat studi gempa nasional tahun 2017. Setelah data dikumpulkan, kemudian data tanah tersebut diolah untuk mendapatkan parameter tanah. Lalu langkah selanjutnya adalah menganalisis potensi likuifaksi pada lokasi penelitian. Metode analisis yang digunakan adalah metode Tsuchida Chart dan metode NCEER. Dengan mempertimbangakan distibusi butiran tanah di lokasi penelitian, metode tsuchida chart cukup efektif digunakan sebagai analisis pendahuluan dalam mengidentifikasi potensi likuifaksi. Setelah itu, dilanjutkan dengan analisis menggunakan metode NCEER yang dalam analisisnya membutuhkan data site class, muka air tanah, magnitude, dan PGA. Nilai safety factor merupakan indikator terjadi atau tidaknya likuifaksi pada tanah tersebut. Apabila terjadi likuifaksi, Langkah pertama adalah menganalisis potensi penurunan daya dukung tiang tunggal pondasi, baik aksial tekan, tarik, dan lateral menggunakan Software Lpile v.5.0. Penelitian ini akan menganalisis beberapa ukuran diameter tiang pondasi diantaranya : 400, 500, dan $600 \mathrm{~mm}$. Ukuran diameter tiang pondasi tersebut diasumsikan sebagai ukuran yang paling sering digunakan dan mudah didapatkan pada suatu pelaksanaan proyek konstruksi. Dengan mendapatkan variasi nilai penurunan daya dukung tiang pada beberapa diameter tiang, maka dapat ditentukan ukuran mana yang paling efektif untuk digunakan. Langkah berikutnya adalah menyusun dan membandingkan konfigurasi pondasi tiang kelompok sebelum dan sesudah likuifaksi terjadi menggunakan Software GROUP v.8.0. mLalu langkah terakhir adalaha menganalisis metode perbaikan tanah dengan menggunakan stone column sebagai metode perbaikan tanah, hasil yang didapat adalah spasi, diameter, pola, dan parameter stone column yang ideal diaplikasikan di lapangan. Hasil yang diharapkan dari penelitian ini adalah menghadirkan solusi untuk memitigasi masalah likuifaksi di lokasi penelitian.

\section{HASIL DAN PEMBAHASAN}

\subsection{Analisis Potensi Likuifaksi}

Analisis potensi likufaksi dilakukan dengan menggunakan metode simplifikasi (NCEER) dan metode tsuchida chart. Hasil dari kedua metode ini kemudian akan dibandingkan untuk mendapatkan kesimpulan dari pengolahan masing- masing metode. 


\subsubsection{Analisis Potensi Likuifaksi dengan Metode Simplifikasi (NCEER)}

Dalam analisis likuifaksi dengan metode simplifikasi, hal seperti yang telah dijelaskan pada bab sebelumnya, dalamanalisis dengan menggunakan metode simplifikasi dibutuhkan nilai Cyclic Stress Ratio (CSR) dan Cyclic ResistanceRatio (CRR) untuk mendapatkan nilai Factor of Safety (FS). Kriteria desain FS yang digunakan pada penelitian iniadalah 1, Jika nilai FS lebih besar dari 1 maka tanah tidak berpotensi likuifaksi. Dalam menghitung nilai CSRdibutuhkan parameter percepatan gempa maksimum di permukaan $\left(a_{\max }\right)$. Berdasarkan peta deagregasi magnitude (M)pada PGA dengan $2 \%$ probabilitas terlampaui dalam 50 tahun (periode ulang gempa 2500 tahun) dan peta percepatanpuncak di batuan dasar untuk probabilitas terlampaui $2 \%$ dalam 50 tahun (Peta Sumber dan Bahaya Gempa IndonesiaTahun 2017) untuk lokasi Lombokdidapatkan nilai PGA ada dinilai $0.6 \mathrm{~g}$ dan untuk nilai M ada dinilai 6.8 SR. Berdasarkan pengecekan dengan SNI 1726-2012. Didapatkan bahwa kelas situs adalah SE. Lalu didapatkan dari tabeldengan site class SE dan PGA $=0.6$, faktor amplifikasinya adalah 1.2. Untuk contoh perhitungan analisisnya dapatdilihat pada tabel berikut:

Tabel 2 Perhitungan potensi likuifaksi metode simplifikasi BH-01

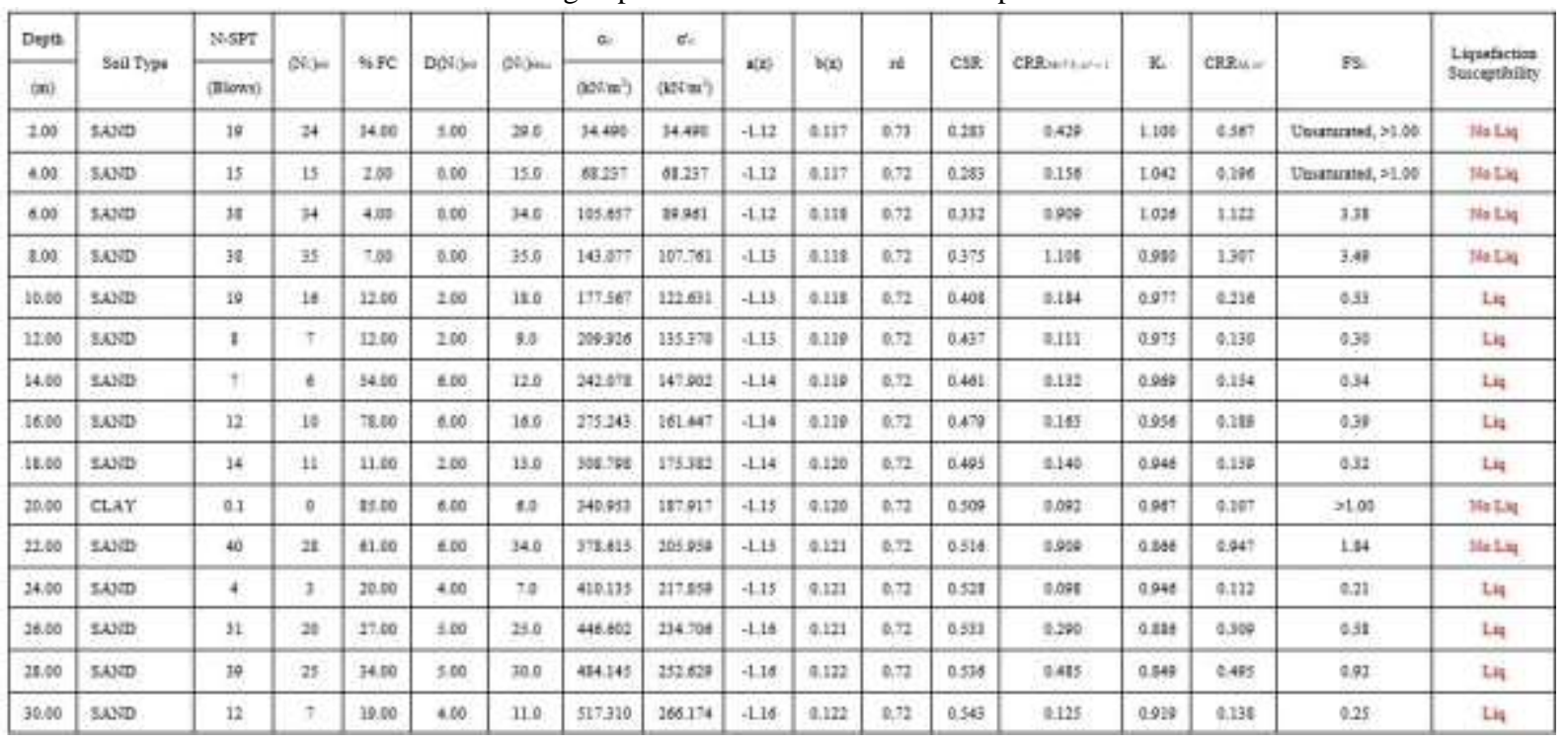

\subsubsection{Analisis Potensi Likuifaksi dengan Metode Tsuchida Chart}

Metode ini sangat membutuhkan hasil dari data lab, yakni grain size analysis. Hasil dari data lab tersebut diplotkan ke tsuchida chart. Maka analisis ini dengan menggunakan metode ini dapat di ketahui hasilnya, seperti pada contoh grafikberikut ini:

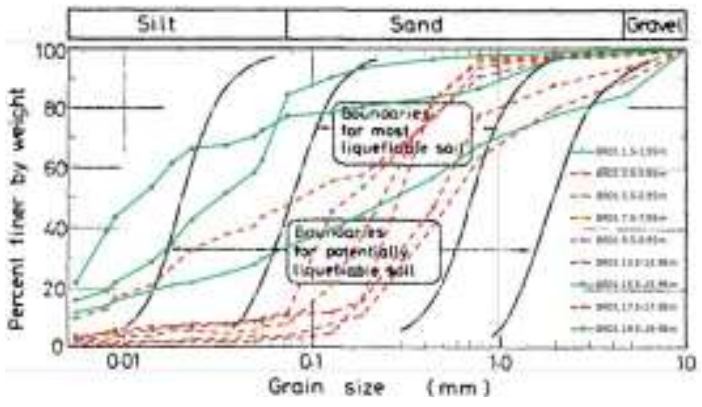

Gambar 2 Hasil analisis metode tsuchida chart untuk BH-01

Berikut perkiraan lapisan yang berpotensi likuifaksi berdasarkan anaisis metode NCEER dan Tsucida Chart. 


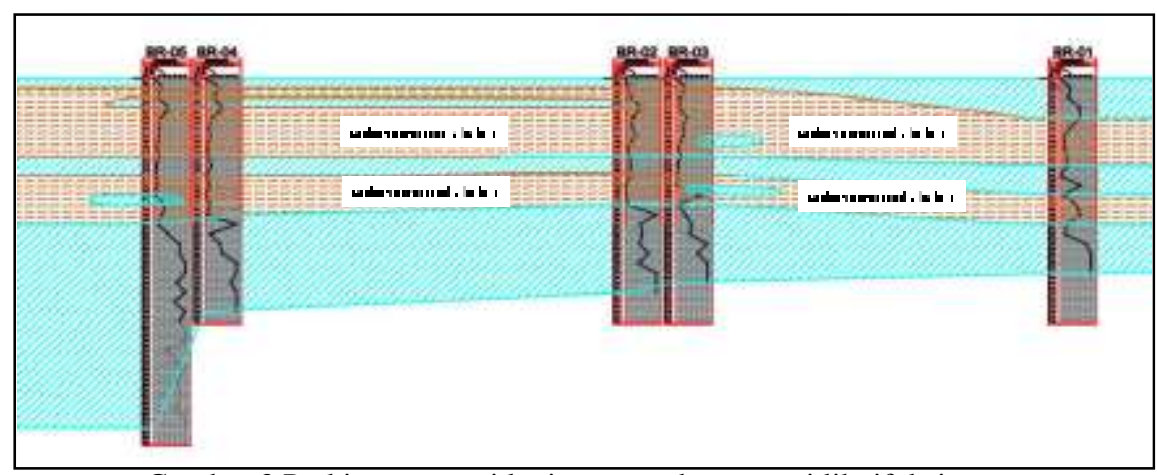

Gambar 3 Perkiraan zonasi lapisan yang berpotensi likuifaksi

\subsection{Daya Dukung Aksial Pondasi Tiang Tunggal}

Perhitungan daya dukung tiang aksial dilakukan pada setiap titik data bor penyelidikan tanah dengan tipe tiang Concrete Spun Pile, kedalaman tiang hingga lapisan tanah keras, serta diameter $400 \mathrm{~mm}, 500 \mathrm{~mm}$, dan $600 \mathrm{~mm}$ Parameter yang digunakan berdasarkan hasil uji SPT dan uji laboratorium. Dari tabel 3 menunjukan hasil daya dukung izin tekan telah mencapai kapasitas maksimum tekan tiang, hal tersebut dikarenakan kedalaman tiang tertanam telah mencapai kedalaman tanah keras atau disebut end bearing pile. Untuk daya dukung izin tarik yang diperlihatkan pada tabel 4 berkisar pada 298 - $652 \mathrm{kN}$. Pada kondisi setelah terjadinya likuifaksi lapisan tanah mengalami kehilangan kekuatan tahanan kepada tiang. Dengan kata lain dapat dikatakan bahwa pada lapisan tanah yang terjadi likuifaksi daya dukung selimutnya bernilai nol. Perbedaan atau selisih kapasitas izin tekan tiang kondisi sebelum dan setelah likuifaksi di tampilkan pada tabel 3

Tabel 3 reduksi daya dukung aksial tekan tiang tunggal

\begin{tabular}{|c|c|c|c|c|}
\hline \multirow{2}{*}{ Titik Bor } & $\begin{array}{c}\text { Pile } \\
\text { Diameter }\end{array}$ & \multicolumn{2}{|c|}{ Kapasitas Izin Tekan (kN) } & \multirow{2}{*}{ Reduksi (\%) } \\
\cline { 2 - 4 } & Mm & Sebelum Likuifaksi & Setelah Likuifaksi & \\
\hline BH-01 & 400 & 1140 & 1140 & $0 \%$ \\
\hline BH-02 & 400 & 1140 & 1140 & $0 \%$ \\
\hline BH-03 & 400 & 1140 & 1140 & $0 \%$ \\
\hline BH-04 & 400 & 1140 & 1140 & $0 \%$ \\
\hline BH-05 & 400 & 1140 & 1140 & $0 \%$ \\
\hline BH-01 & 500 & 1750 & 1750 & $0 \%$ \\
\hline BH-02 & 500 & 1750 & 1750 & $0 \%$ \\
\hline BH-03 & 500 & 1750 & 1750 & $0 \%$ \\
\hline BH-04 & 500 & 1750 & 1750 & $0 \%$ \\
\hline BH-05 & 500 & 1750 & 1750 & $0 \%$ \\
\hline BH-01 & 600 & 2380 & 2380 & $0 \%$ \\
\hline BH-02 & 600 & 2380 & 2380 & $0 \%$ \\
\hline BH-03 & 600 & 2380 & 2380 & $0 \%$ \\
\hline BH-04 & 600 & 2380 & 2380 & $0 \%$ \\
\hline BH-05 & 600 & 2380 & 2380 & $0 \%$ \\
\hline & \multicolumn{3}{|l}{} & $0.00 \%$ \\
\hline
\end{tabular}

Berdasarkan tabel di atas reduksi yang terjadi pada daya dukung aksial arah tekan terlihat bahwa reduksi yang terjadi bernilai $0 \%$ atau dapat dikatakan likuifaksi tidak berpengaruh terhadap daya dukung aksial tekan. Hal tersebut dikarenakan karena daya dukung aksial tekan telah mencapai kapasitas maksimumnya dimana ujung tiang telah tertanam pada lapisan tanah keras. Untuk selisih kapasitas izin tarik tiang kondisi sebelum dan setelah likuifaksi di tampilkan pada tabel 4:

Tabel 4 reduksi daya dukung aksial tarik tiang tunggal

\begin{tabular}{|c|c|c|c|c|}
\hline \multirow{2}{*}{ Titik Bor } & $\begin{array}{c}\text { Pile } \\
\text { Diameter }\end{array}$ & \multicolumn{2}{|c|}{ Kapasitas Izin Tarik (kN) } & \multirow{2}{*}{ Reduksi (\%) } \\
\cline { 2 - 4 } & $\mathrm{Mm}$ & Sebelum Likuifaksi & Setelah Likuifaksi & \\
\hline BH-01 & 400 & 324 & 320 & $1 \%$ \\
\hline BH-02 & 400 & 298 & 159 & $47 \%$ \\
\hline BH-03 & 400 & 324 & 304 & $6 \%$ \\
\hline BH-04 & 400 & 324 & 225 & $31 \%$ \\
\hline BH-05 & 400 & 324 & 261 & $19 \%$ \\
\hline BH-01 & 500 & 488 & 407 & $17 \%$ \\
\hline BH-02 & 500 & 378 & 204 & $46 \%$ \\
\hline BH-03 & 500 & 488 & 386 & $21 \%$ \\
\hline
\end{tabular}


Tabel 4 reduksi daya dukung aksial tarik tiang tunggal (lanjutan)

\begin{tabular}{|c|c|c|c|c|}
\hline Titik Bor & $\begin{array}{c}\text { Pile } \\
\text { Diameter }\end{array}$ & \multicolumn{2}{|c|}{ Kapasitas Izin Tarik (kN) } & Reduksi (\%) \\
\hline BH-04 & 500 & 423 & 287 & $32 \%$ \\
\hline BH-05 & 500 & 473 & 333 & $30 \%$ \\
\hline BH-01 & 600 & 652 & 494 & $24 \%$ \\
\hline BH-02 & 600 & 459 & 249 & $46 \%$ \\
\hline BH-03 & 600 & 652 & 470 & $28 \%$ \\
\hline BH-04 & 600 & 513 & 349 & $32 \%$ \\
\hline BH-05 & 600 & 574 & 406 & $29 \%$ \\
\hline \multicolumn{4}{|c|}{ Reduksi Rata - rata } & $27 \%$ \\
\hline
\end{tabular}

Tabel di atas menunjukan hasil reduksi kapasitas izin tarik yang terjadi berkisar 1 hingga $47 \%$ dengan nilai rata - rata reduksi $27 \%$.

\subsection{Daya Dukung Lateral Pondasi Tiang Tunggal}

Daya dukung lateral tiang dihitung menggunakan Software LPile v.5.0., dimana Software LPile v.5.0. melakukan perhitungan berulang hingga memenuhi static equilibrium (kesetimbangan statis) dan mencapai kompatibilitas yang dapat diterima antara gaya dan defleksi (p dan y) di setiap elemen. Jenis yang digunakan adalah tiang Concrete Spun Pile dengan tipe kelas B. Pada Error! Reference source not found. menunjukan hasil kisaran kapasitas lateral tiang berada pada rentang $27-135 \mathrm{kN}$ untuk kondisi tanpa mempertimbangkan kondisi likuifaksi. Defleksi maksimal pada tiang dibatasi sebesar 0.5 inch atau $12.5 \mathrm{~mm}$. Bending Moment maksimal pada tiang kelas B adalah $75 \mathrm{kN}$-m untuk CSP 400, $150 \mathrm{kN}$-m untuk CSP 500, dan $250 \mathrm{kN}-\mathrm{m}$ untuk CSP 600. Seperti halnya pada daya dukung aksial, lapisan tanah yang terjadi likuifaksi mengalami kehilangan tahanan selimutnya sehingga daya dukung lateral tiang tunggal mengalami penurunan dibandingkan dengan kondisi sebelum terjadi likuifaksi. Untuk nilai reduksi kapasitas lateral tiang yang terjadi ditampilkan pada tabel berikut:

Tabel 5 Reduksi kapasitas lateral tiang

\begin{tabular}{|c|c|c|c|c|c|c|c|c|c|}
\hline \multirow[t]{2}{*}{ No } & \multirow[t]{2}{*}{ Titik Bor } & \multirow[t]{2}{*}{ Tipe Tiang } & \multirow[t]{2}{*}{ Kelas } & D & $\mathbf{L}$ & Kepala Tiang & $\begin{array}{c}\text { Kap. Lateral } \\
\text { (sebelum Liq) }\end{array}$ & $\begin{array}{l}\text { Kap. Lateral } \\
\text { (setelah Liq) }\end{array}$ & Reduksi \\
\hline & & & & $\mathrm{m}$ & $\mathrm{m}$ & Free/ Fixed Head & $\mathrm{KN}$ & $\mathrm{KN}$ & $(\mathrm{kN})$ \\
\hline 1 & BR-01 & $\mathrm{CSP}$ & $\bar{B}$ & 0.4 & 34 & Free Head & 35 & 35 & $0 \%$ \\
\hline 2 & BR-01 & CSP & B & 0.4 & 34 & Fixed Head & 50 & 50 & $0 \%$ \\
\hline 3 & BR-01 & CSP & B & 0.5 & 34 & Free Head & 52 & 52 & $0 \%$ \\
\hline 4 & BR-01 & CSP & $\mathrm{B}$ & 0.5 & 34 & Fixed Head & 85 & 85 & $0 \%$ \\
\hline 5 & BR-01 & CSP & $\mathrm{B}$ & 0.6 & 34 & Free Head & 75 & 75 & $0 \%$ \\
\hline 6 & BR-01 & CSP & B & 0.6 & 34 & Fixed Head & 125 & 125 & $0 \%$ \\
\hline 7 & BR-02 & $\overline{\mathrm{CSP}}$ & $\overline{\mathrm{B}}$ & 0.4 & 28 & Free Head & 27 & 20 & $26 \%$ \\
\hline 8 & BR-02 & CSP & $\mathrm{B}$ & 0.4 & 28 & Fixed Head & 45 & 39 & $13 \%$ \\
\hline 9 & BR-02 & CSP & $\mathrm{B}$ & 0.5 & 28 & Free Head & 40 & 29 & $28 \%$ \\
\hline 10 & BR-02 & CSP & $\mathrm{B}$ & 0.5 & 28 & Fixed Head & 74 & 65 & $12 \%$ \\
\hline 11 & BR-02 & CSP & $\mathrm{B}$ & 0.6 & 28 & Free Head & 58 & 41 & $29 \%$ \\
\hline 12 & BR-02 & CSP & B & 0.6 & 28 & Fixed Head & 110 & 95 & $14 \%$ \\
\hline 13 & BR-03 & CSP & $\bar{B}$ & 0.4 & 34 & Free Head & 35 & 24 & $31 \%$ \\
\hline 14 & BR-03 & CSP & B & 0.4 & 34 & Fixed Head & 50 & 40 & $20 \%$ \\
\hline 15 & BR-03 & CSP & $\mathrm{B}$ & 0.5 & 34 & Free Head & 52 & 30 & $42 \%$ \\
\hline 16 & BR-03 & CSP & B & 0.5 & 34 & Fixed Head & 85 & 50 & $41 \%$ \\
\hline 17 & BR-03 & CSP & B & 0.6 & 34 & Free Head & 70 & 37 & $47 \%$ \\
\hline 18 & BR-03 & CSP & B & 0.6 & 34 & Fixed Head & 120 & 63 & $48 \%$ \\
\hline 19 & BR-04 & $\overline{C S P}$ & $\bar{B}$ & 0.4 & 30 & Free Head & 45 & 36 & $20 \%$ \\
\hline 20 & BR-04 & CSP & B & 0.4 & 30 & Fixed Head & 57 & 52 & $9 \%$ \\
\hline 21 & BR-04 & CSP & B & 0.5 & 30 & Free Head & 67 & 49 & $27 \%$ \\
\hline 22 & BR-04 & CSP & B & 0.5 & 30 & Fixed Head & 93 & 81 & $13 \%$ \\
\hline 23 & BR-04 & CSP & B & 0.6 & 30 & Free Head & 90 & 65 & $28 \%$ \\
\hline 24 & BR-04 & CSP & B & 0.6 & 30 & Fixed Head & 135 & 118 & $13 \%$ \\
\hline 25 & BR-05 & CSP & B & 0.4 & 34 & Free Head & 32 & 23 & $28 \%$ \\
\hline 26 & BR-05 & CSP & B & 0.4 & 34 & Fixed Head & 48 & 41 & $15 \%$ \\
\hline 27 & BR-05 & CSP & B & 0.5 & 34 & Free Head & 47 & 33 & $30 \%$ \\
\hline 28 & BR-05 & CSP & B & 0.5 & 34 & Fixed Head & 80 & 67 & $16 \%$ \\
\hline 29 & BR-05 & CSP & $\mathrm{B}$ & 0.6 & 34 & Free Head & 65 & 46 & $29 \%$ \\
\hline 30 & BR-05 & CSP & B & 0.6 & 34 & Fixed Head & 115 & 99 & $14 \%$ \\
\hline
\end{tabular}

Tabel diatas menunjukan hasil reduksi daya dukung lateral tiang berkisar $0-48 \%$.

\subsection{Daya Dukung Pondasi Tiang Grup}

Dengan menggunakan asumsi beban struktur pada bangunan 3 lantai, tiang grup untuk struktur bangunan ini direncanakan menggunakan tiang pancang berdiameter $600 \mathrm{~mm}$, panjang tiang $30 \mathrm{~m}$, jumlah tiang 121 dengan konfigurasi 11 (arah memanjang) dan 11 (arah melintang) bangunan. Jarak antar tiang arah memanjang dan melintang sama, yaitu $1.5 \mathrm{~m}$. Parameter yang dipakai mencakup properties tiang pancang, konfigurasi tiang grup, parameter tanah, dan kombinasi pembebanan. Untuk kondisi likuifaksi, properties tiang pancang yang digunakan sama dengan kondisi sebelum likuifaksi, hanya ada pertambahan jumlah tiang sebanyak 169 dengan konfigurasi 13 (arah memanjang) dan 13 
(arah melintang) bangunan. Jumlah tiang lebih banyak dibandingkan kondisi sebelum terjadi likuifaksi dikarenakan lapisan tanah yang mengalami likuifaksi mengalami kehilangan tahanan selimutnya. Asumsi perhitungan pada lapisan tanah yang berpotensi terjadi likuifaksi dimodelkan dengan menggunakan liquefiable sand dimana lapisan tanah tersebut tidak memiliki tahanan selimut terhadap tiang pancang. Perhitungan numerik tiang grup dilakukan menggunakan Software GROUP v.8.0. Dengan mengaplikasikan beban-beban sesuai dengan yang telah direncanakan sebelumnya, hasil output program Group v.8.0.9 terhadap pembebanan lateral dapat dilihat pada gambar 4 dan 5:

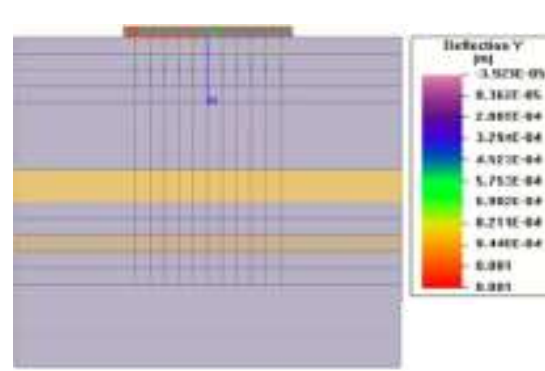

(a)

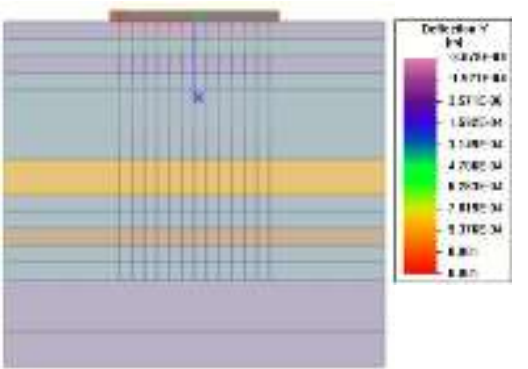

(b)

Gambar 42 (a) Defleksi Kepala Tiang Arah y Kondisi Sebelum Likuifaksi

(b) Defleksi Kepala Tiang Arah y Kondisi Setelah Likuifaksi

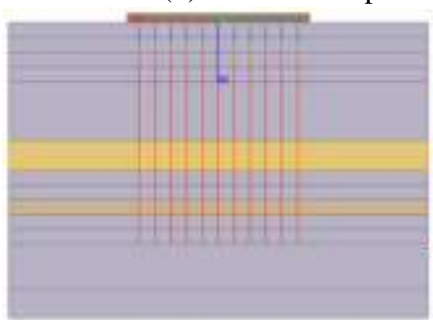

(a)

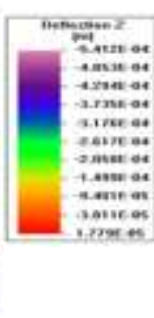

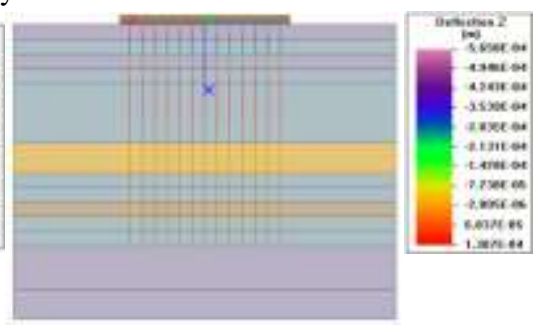

(b)

(b) Defleksi Kepala Tiang Arah z Kondisi Setelah Likuifaksi

Perhitungan gaya dalam pondasi tiang pancang mencakup gaya aksial, gaya momen, dan gaya geser. Tujuan dari perhitungan ini adalah untuk merencanakan kapasitas aksial dan tulangan masing-masing tiang pancang. Besar gaya aksial yang timbul pada tiap tiang pancang harus mampu dipikul oleh daya dukung izin, gaya momen yang terjadi pada tiap-tiap tiang pancang harus mampu ditahan oleh tulangan longitudinal, dan besar gaya geser yang ada harus mampu ditahan oleh tulangan geser. Berikut ini adalah hasil analisis gaya aksial tekan yang terjadi pada tiap-tiap tiang pancang menggunakan Software GROUP v.8.0. :

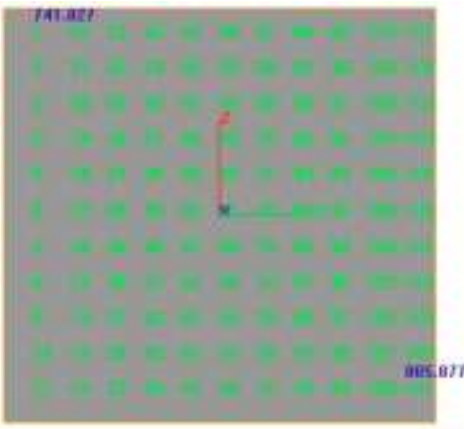

(a)

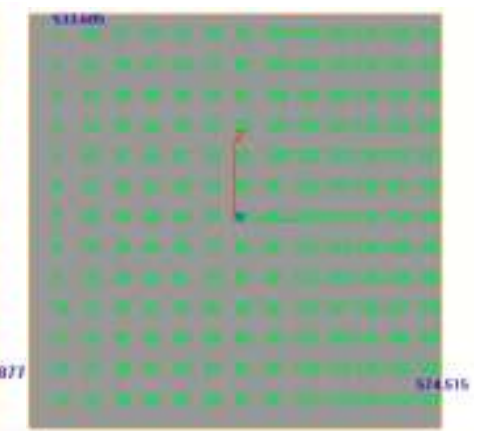

(b)

Gambar 6 (a) Gaya Aksial Tekan Pondasi Kondisi Sebelum Likuifaksi

(b) Gaya Aksial Tekan Pondasi Kondisi Setelah Likuifaksi 


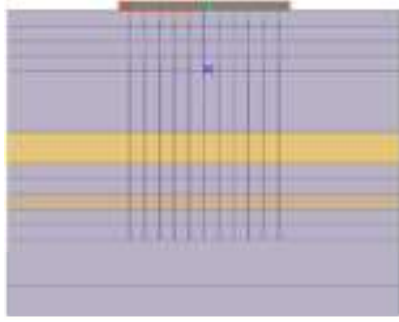

(a)

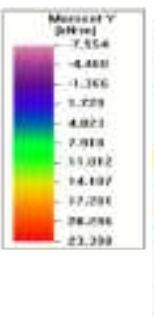

Gambar 74 (a) Momen Arah y Kondisi Sebelum Likuifaksi Momen Arah y Kondisi Setelah Likuifaksi

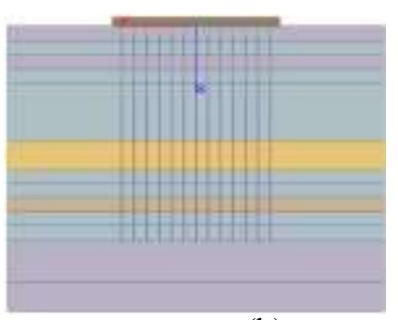

(b)

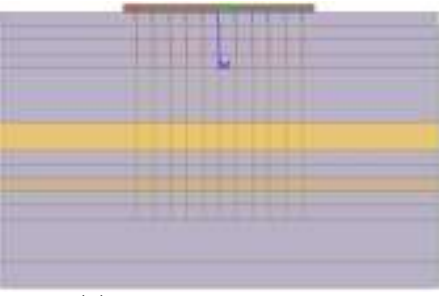

(a)

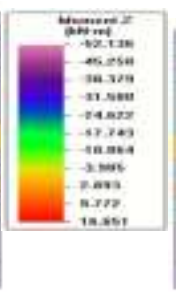

Gambar 8 (a) Momen Arah z Kondisi Sebelum Likuifaksi

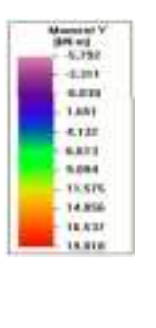

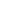


Tabel 8 Perhitungan potensi likuifaksi dengan perbaikan stone column

\begin{tabular}{|c|c|c|c|c|c|c|c|c|c|c|c|c|c|c|}
\hline \multirow{2}{*}{$\begin{array}{c}\text { Depth } \\
(\mathrm{m})\end{array}$} & \multirow{2}{*}{$\begin{array}{l}\text { Soil } \\
\text { Type }\end{array}$} & \multirow{2}{*}{$\begin{array}{c}\text { N-SPT } \\
\text { (Blows) }\end{array}$} & \multicolumn{5}{|c|}{ SPT Corection Factors } & \multirow{2}{*}{$\left(\mathrm{N}_{1}\right)_{60}$} & \multicolumn{2}{|c|}{ BEFORE IMPROVEMENT } & \multirow{2}{*}{$\alpha$} & \multirow{2}{*}{$\mathrm{CSR}_{\text {Priebe }}$} & \multicolumn{2}{|c|}{ AFTER IMPROVEMENT } \\
\hline & & & $\mathrm{C}_{\mathrm{N}}$ & $\mathrm{C}_{\mathrm{E}}$ & $\mathrm{C}_{\mathrm{B}}$ & $\mathrm{C}_{\mathrm{R}}$ & $\mathrm{C}_{\mathrm{S}}$ & & $\mathrm{FS}_{\mathrm{L}}$ & $\begin{array}{l}\text { Liquefaction } \\
\text { Susceptibility }\end{array}$ & & & FoS & Liquefaction \\
\hline 2.00 & SAND & 15 & 1.70 & 1.00 & 1.00 & 0.75 & 1.00 & 19 & Unsaturated, $>1.00$ & No Liq & 0.10 & 0.027 & 12.83 & No Liq \\
\hline 4.00 & SAND & 6 & 1.35 & 1.00 & 1.00 & 0.80 & 1.00 & 6 & 0.35 & Liq & 0.10 & 0.032 & 3.47 & No Liq \\
\hline 6.00 & SAND & 30 & 1.18 & 1.00 & 1.00 & 0.85 & 1.00 & 30 & 1.56 & No Liq & 0.10 & 0.038 & 15.29 & No Liq \\
\hline 8.00 & SAND & 13 & 1.08 & 1.00 & 1.00 & 0.95 & 1.00 & 13 & 0.39 & Liq & 0.10 & 0.043 & 3.96 & No Liq \\
\hline 10.00 & SAND & 9 & 1.01 & 1.00 & 1.00 & 0.95 & 1.00 & 9 & 0.28 & Liq & 0.10 & 0.046 & 2.92 & No Liq \\
\hline 12.00 & SAND & 10 & 0.95 & 1.00 & 1.00 & 1.00 & 1.00 & 9 & 0.26 & Liq & 0.10 & 0.048 & 2.77 & No Liq \\
\hline 14.00 & SAND & 5 & 0.90 & 1.00 & 1.00 & 1.00 & 1.00 & 5 & 0.19 & Liq & 0.10 & 0.050 & 2.05 & No Liq \\
\hline 16.00 & SAND & 9 & 0.86 & 1.00 & 1.00 & 1.00 & 1.00 & 8 & 0.23 & Liq & 0.10 & 0.052 & 2.41 & No Liq \\
\hline 18.00 & CLAY & 4 & 1.00 & 1.00 & 1.00 & 1.00 & 1.00 & 4 & $>1.00$ & No Liq & 0.10 & 0.053 & 2.67 & No Liq \\
\hline 20.00 & CLAY & 4 & 1.00 & 1.00 & 1.00 & 1.00 & 1.00 & 4 & $>1.00$ & No Liq & 0.10 & 0.054 & 2.63 & No Liq \\
\hline 22.00 & SAND & 7 & 0.75 & 1.00 & 1.00 & 1.00 & 1.00 & 5 & 0.18 & Liq & 0.10 & 0.055 & 2.01 & No Liq \\
\hline 24.00 & SAND & 0.1 & 0.73 & 1.00 & 1.00 & 1.00 & 1.00 & 0 & 0.13 & Liq & 0.10 & 0.056 & 1.40 & No Liq \\
\hline 26.00 & CLAY & 22 & 1.00 & 1.00 & 1.00 & 1.00 & 1.00 & 22 & $>1.00$ & No Liq & 0.10 & 0.056 & 7.46 & No Liq \\
\hline 28.00 & SAND & 15 & 0.67 & 1.00 & 1.00 & 1.00 & 1.00 & 10 & 0.24 & Liq & 0.10 & 0.056 & 2.67 & No Liq \\
\hline 30.00 & SAND & 8 & 0.65 & 1.00 & 1.00 & 1.00 & 1.00 & 5 & 0.17 & Liq & 0.10 & 0.057 & 1.94 & No Liq \\
\hline
\end{tabular}

Tabel di atas menunjukan hasil perhitungan antara sebelum dan sesudah perbaikan. Pada beberapa lapisan tanah yang sebelumnya berpotensi likuifaksi menjadi tidak berpotensi likuifaksi karena dengan adanya stone column.

\section{KESIMPULAN}

Berikut beberapa kesimpulan yang dapat diambil berdasarkan hasil penelitian:

1. Dengan metode NCEER dan tsuchida chart dapat disimpulkan bahwa tanah pada kelima titik tinjau mengindikasikan potensi likuifaksi. Kedalaman potensi likuifaksi bervariasi, lapisan yang tidak berpotensi likuifaksi merupakan lapisan yang mempunyai nilai N-SPT yang tinggi $(\mathrm{N}>50)$ dan berada pada lapisan terdalam. Hal ini mengindikasikan likuifaksi cenderung tidak terjadi pada lapisan dengan kepadatan relatif yang besar dan memiliki nilai uji NSPT yang besar.

2. Daya dukung aksial tekan tidak mengalami reduksi daya dukung, hal ini dikarenakan ujung tuang tertanam pada lapisan tanah keras sehingga daya dukung aksial tekan telah mencapai kapasitas maksimumnya. Untuk daya dukung aksial tarik reduksi yang terjadi berkisar 1\% hingga 47\%. Sedangkan, dengan kondisi likuifaksi daya dukung lateral mengalami reduksi berkisar 0 hingga $48 \%$.

3. Pada analisis daya dukung tiang grup jumlah tiang yang diperlukan ketika kondisi sebelum likuifaksi adalah 121 tiang dengan panjang $30 \mathrm{~m}$. Kemudian jumlah tiang yang diperlukan untuk kondisi setelah terjadi likuifaksi adalah 169 tiang dengan panjang tiang $30 \mathrm{~m}$. Selisih tiang yang diperlukan adalah 48 tiang.

4. Perbaikan tanah yang cocok pada lokasi studi adalah stone column, selain dapat mengantisipasi terjadinya likuifaksi, stone column dapat meningkatkan daya dukung tanah.

Adapun saran terkait penelitian ini adalah, perlu dilakukan tinjauan pada lokasi lain dengan kondisi tanah yang berbeda, sehingga alternatif perbaikan tanah bisa divariasikan.

\section{DAFTAR PUSTAKA}

Ishihara, K. dan Cubrinovski, M. 1998. Soil-Pile Inteaction in Liquefied Deposits Undergoing Lateral Spreading. Croatia: XI Danube-European Conference.

Martin, G.R., Finn, W.D. Liam and Seed, H.B. 1975. Fundamentals of Liquefaction Under Cyclic Loading. Journals of the Geotechnical Eng. Division, ASCE, vol. 101, No. GT5

Pusat Studi Gempa Nasional. 2017. Peta Sumber Dan Bahaya Gempa Indonesia Tahun 2017. Jakarta: Pusat Penelitian dan Pengembangan Perumahan dan Permukiman.

Seed, H. B., and Idriss, I. M. 1982. Ground motions and soil liquefaction during earthquakes. California: Earthquake Engineering Research Institute Monograph.

Standar Nasional Indonesia (2017). Persyaratan Perancangan Geoteknik (SNI 8460:2017). Badan Standardisasi Nasional.

Tsuchida, H. 1970. Prediction and Countermeasure against Liquefaction in Sand Deposits. Proceeding of Abstract of the Seminar of the Port and Harbour Research Institute. Japan : Ministry of Transport.

Youd, T.L and Idriss, I.M. 2001. Liquafaction Resistance of Soils : Summary report from the 1996 NCEER and 1998 NCEERR/NSF Workshop on Evaluation of Liquefaction Resistance of Soils, Journal of Geotechnical and Geoenvironmental Engineering, April 2001. 